\title{
Effect of Debittering Methods on the Proximate Composition Sensory and Functional Properties of Orange (Citrus Sinensis) Seed Flour
}

\author{
Eguono Ernest Emojorho ${ }^{1}$, Peter Isah Akubor ${ }^{2}$ \\ ${ }^{I}$ (Department of Food Science and Technology, University of Nigeria,Nsukka, Nigeria) \\ ${ }^{2}$ (Department of Food Science and Technology, Federal University, Wukari, Nigeria)
}

\begin{abstract}
The study determined the effect of debittering methods on the quality of flours prepared from orange seeds. Orange seeds were removed from orange fruits, washed and then sundried at $30 \pm 2{ }^{\circ} \mathrm{C}$ for $8 \mathrm{~h}$. Orange seeds (20kg) were soaked in water for 12h, boiled for 40,80,120, and 160min respectively. The boiled seeds were dehulled, ovendried $\left(60{ }^{\circ} \mathrm{C}\right.$ for $\left.14 \mathrm{~h}\right)$ grounded and defatted, milled and sieved. Flours were analyzed for proximate composition, sensory and functional properties. Chemical composition of the flours ranged from protein $8.64 \%-31.81 \%$, fat $1.01 \%-35.72 \%$, crude fiber $0.93 \%-21.82 \%$, ash $0.39 \%-3.01 \%$, moisture content $3.69 \%-11.62 \%$, carbohydrate $32.24 \%-74.94 \%$. The oil absorption capacity of the flours ranged from $1.73 \mathrm{~g} / \mathrm{g}-2.64 \mathrm{~g} / \mathrm{g}$, bulk density ranged from $0.42-0.77 \mathrm{~g} / \mathrm{cm}^{3}$, water absorption capacity ranged from 1.54 $4.67 \mathrm{~g} / \mathrm{g}$, least gelation concentrations ranged from $4 \%$ to $20 \%$, foaming capacity $2.8-21.11 \%$ and foaming stability ranged from $2.0 \%-12.50 \%$. The pasting properties of flour ranged are peak viscosity $50.33 R V U-$ $68.67 R V U$, trough viscosity $46.83 R V U-66.00 R V U$, breakdown viscosity $2.17-4.25 R V U$, setback $73.42 R V U-$ $194.33 R V U$, final viscosity $120.25 R V U-257.33 R V U$, peak time $6.25 \mathrm{~min}-6.55 \mathrm{~min}$, and pasting temperature $82.55-84.15^{\circ} \mathrm{C}$.
\end{abstract}

Keywords: Debittered orange seed flour, Debittering methods, Functional properties, Orange seed, Pasting properties, Proximate composition.

\section{Introduction}

Sweet orange (Citrus sinensis) is the world's most commonly cultivated fruit tree. Orange seeds are usually embedded at the centre of orange fruit, in direct contact with the juice sacs [1]. The seeds are greenish to pale whitish, flattened, and angular. Orange by-products such as the seeds are very worrisome waste capable of causing serious environmental pollution. However, orange fruit wastes are promising materials in the food industries due to their nutritional and technological properties [2]. However, the orange seeds are not used in food processing, because they impact high degree of bitter taste. Thus debittering of orange seeds has long been a major sensory concern in food science. The bitterness in orange seed is caused by limonin in sweet orange [3]. Limonin or its precursor is mainly found in the seeds, including peels, albedo and segment wall of the orange fruit [4]. The seeds of sweet orange fruit contained the highest percentage of about $480 \mathrm{mg} / 100 \mathrm{~g}$ limonin, and least amount of limonin is present in the segment wall $(0.95 \mathrm{mg} / 100 \mathrm{~g})$ [5]. Limonin is produced from limonic acid or limonin monolactone, which is found in the seeds and membranes of most citrus fruits [3]. Bitterness in orange seed is a sensory defect with major economic effect. Excess bitterness affects the quality of many processed orange products which results in significant loss of products due to rejection by consumers.

Orange seed flour has good potential for use as functional agent in bakery products on account of its high water absorption capacity [6]. It is important to study the chemical, pasting and functional properties of the debittered orange seed flour to determine its suitability for use as composite flour. Flour quality can be assessed by functional, pasting and chemical analysis. The effect of debittering methods on the proximate composition, functional and pasting properties of the seed flour has not been demonstrated. The objective of this investigation was to determine the effect of debittering methods such as soaking, boiling and defatting on the proximate composition, functional and pasting characteristic of orange seed flour. 


\section{Material and Methods}

Sweet orange (Citrus sinensis) fruits were purchased from a local market in Enugu State, Nigeria.

\subsection{Preparation of debittered orange seed flour}

The fruits were cut into halves with a clean sharp knife and the seeds were removed. The seeds were cleaned with tap water and sundried $\left(32 \pm 2{ }^{\circ} \mathrm{C}, 8 \mathrm{~h}\right)$. The orange seeds $(20 \mathrm{~kg})$ were soaked in tap water $(1: 10$, seed: water) for $12 \mathrm{~h}$. Thereafter, the hydrated seeds were boiled for 40, 80, 120 and $160 \mathrm{~min}$, respectively. All the samples were dehulled manually, winnowed, oven dried at $60{ }^{\circ} \mathrm{C}$ for $12 \mathrm{~h}$, ground with corolla hand grinding machine, sieved through 60 mesh sieve. Oil was extracted from a portion with ethanol in a Soxhlet apparatus. Flours were analyzed for bitterness by sensory evaluation. The flow chart for the preparation of debittered orange seed flour is shown in Fig 1.

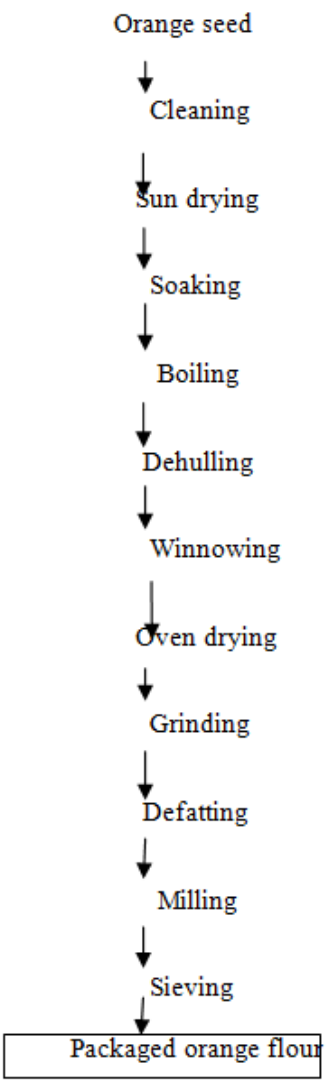

Fig 1. Processing of debittered orange seed flour

\subsection{Sensory evaluation}

The flour samples were evaluated by twenty trained panelists for taste, colour, flavour, texture and general acceptability as described by [7].

\subsection{Evaluation of functional properties}

Water absorption capacity and oil absorption capacity were determined using the procedures of [8]. Least gelation concentration was determined by a modified method of [9]. Foaming capacity, foam stability and bulk density were determined by the methods described by [10].

\subsection{Determination of pasting characteristics}

The individual flours and the flour blends were analyzed for pasting characteristics such as peak time, pasting temperature, peak viscosity, final viscosity, trough viscosity, breakdown viscosity and setback viscosity using a Rapid Visco Analyser (RVA) Series 4 (Newport Scientific Pvt. Ltd., Australia) according to the method of [11]. 


\subsection{Determination of proximate composition}

Moisture, crude protein, ash, fat and crude fiber contents were determined by the methods of [12]. Carbohydrate was calculated by difference [7].

\section{Results and Discussion}

\subsection{Effect of debittering methods on proximate composition of flour}

Table 1: Proximate composition (\%) of wheat flour (WF) and orange seed flours

\begin{tabular}{|l|l|l|l|l|l|l|}
\hline Flours & Moisture & Protein & Fat & Ash & Crude fiber & Carbohydrate \\
\hline Wheat flour & $11.62^{\mathrm{a}} \pm 0.51$ & $11.20^{\mathrm{e}} \pm 0.08$ & $1.01^{\mathrm{e}} \pm 0.03$ & $0.39^{\mathrm{b}} \pm 0.05$ & $0.93^{\mathrm{d}} \pm 0.06$ & $74.94^{\mathrm{a}} \pm 0.62$ \\
\hline $\begin{array}{l}\text { orange seed } \\
\text { flour (untreated) }\end{array}$ & $3.69^{\mathrm{d}} \pm 0.28$ & $8.64^{\mathrm{f}} \pm 0.73$ & $35.72^{\mathrm{a}} \pm 0.78$ & $2.82^{\mathrm{a}} \pm 0.10$ & $8.88^{\mathrm{c}} \pm 0.41$ & $32.24^{\mathrm{d}} \pm 2.04$ \\
\hline OSFB40 & $4.32^{\mathrm{d}} \pm 0.21$ & $18.93^{\mathrm{d}} \pm 0.73$ & $23.72^{\mathrm{b}} \pm 0.78$ & $3.01^{\mathrm{a}} \pm 0.56$ & $18.25^{\mathrm{b}} \pm 0.06$ & $32.30^{\mathrm{d}} \pm 0.19$ \\
\hline OSFB80 & $7.32^{\mathrm{bc}} \pm 0.69$ & $26.71^{\mathrm{b}} \pm 0.51$ & $3.71^{\mathrm{d}} \pm 0.06$ & $2.63^{\mathrm{a}} \pm 0.19$ & $18.29^{\mathrm{b}} \pm 0.08$ & $41.33^{\mathrm{bc}} \pm 1.11$ \\
\hline OSFB120 & $6.66^{\mathrm{c}} \pm 0.54$ & $24.06^{\mathrm{c}} \pm 0.63$ & $4.97^{\mathrm{c}} \pm 0.67$ & $2.55^{\mathrm{a}} \pm 0.22$ & $18.48^{\mathrm{b}} \pm 0.20$ & $43.28^{\mathrm{b}} \pm 1.87$ \\
\hline OSFB160 & $7.63^{\mathrm{b}} \pm 0.24$ & $31.81^{\mathrm{a}} \pm 0.75$ & $3.06^{\mathrm{d}} \pm 0.56$ & $2.61^{\mathrm{a}} \pm 0.38$ & $21.82^{\mathrm{a}} \pm 0.21$ & $33.07^{\mathrm{d}} \pm 2.04$ \\
\hline
\end{tabular}

Means within a column with the same superscript were not significantly different $(\mathrm{P}>0.05) . \mathrm{OSF}=$ orange seed flour, OSFB $40=$ orange seed flour boiled for $40 \mathrm{~min}, \mathrm{OSFB} 80=$ orange seed flour boiled for $80 \mathrm{~min}$, OSFB120 = orange seed flour boiled for $120 \mathrm{~min}$ and OSFB160 = orange seed flour boiled for $160 \mathrm{~min}$. All the treated flours were partially defatted.

The moisture contents of the samples ranged from $3.69 \%-11.62 \%$. Wheat flour had the highest moisture content $(11.62 \%)$ while the orange seed flour had the least moisture content $(3.69 \%)$. The debittering methods increased the moisture content of the orange seed flour to a range of $4.32 \%-7.63 \%$. Boiling period increased the moisture content due to absorption of water by seeds during cooking [13]. The low moisture contents would enhance the orange seed flour storage stability. There were significant differences $(\mathrm{P}<0.05)$ in the protein content of the flour samples. The protein content of dehulled orange seed flour $(8.64 \%)$ was lower than that of wheat flour $(11.20 \%)$. However, this value was higher than the value of $3.1 \%$ previously reported by [6] for dehulled orange seed flour but lower than $17.9 \%$ reported by [14] for bitter orange seed flour. The difference observed may be contributed by varietal differences, degree maturation of the seeds and environmental conditions [15]. The protein content of the debittered orange seed flours varied from $18.93 \%$ $31.81 \%$. The debittering methods increased the protein content of orange seed flour. Defatting increased protein concentration [16]. Similar observation was reported by [17] [18]. Increase in the boiling period increased the protein concentration of the debittered orange seed flours. The changes in protein content were due to increase of boiling time.

The fat contents of the various flours samples differed significantly $(\mathrm{p}<0.05)$. The fat content was highest in orange seed flour $(35.72 \%)$. The result was similar to $34 \%$ fat reported for orange seed by [19] and lower than $54 \%$ fat reported by [6] for orange seed flour. The wheat flour had $1.01 \%$ fat. The fat contents of the debittered orange seed flours varied from $3.06 \%-23.72 \%$. The fat content decreased with increased in the boiling time. The seeds boiled for $40 \mathrm{~min}$ had higher fat content $(23.72 \%)$ than those of the seeds boiled for 80 , 120, and 160 mins which were $3.71 \%, 4.97 \%$, and $3.06 \%$ fat contents respectively. The reduction in fat content of the orange seed flour reduced the bitterness of the orange seed flour (based on sensory evaluation). The ash content of wheat flour $(0.39 \%)$ was lower than that of the orange seed flour $(2.82 \%)$. The ash content of the orange seed flour was comparable to the $2.5 \%$ reported by [6] for orange seed flour. The ash content of the orange seed was not affected by the debittering methods. The ash content of the debittered orange seed flours ranged from $2.55 \%-3.01 \%$. Ash content is an indication of the mineral content [20]. Minerals provide structure to bones and teeth and participate in energy production, the building of protein, blood formation and several other metabolic processes [21]. The crude fiber contents ranged from $0.93 \%-21.82 \%$, with the highest value for the $160 \mathrm{~min}$ boiled and defatted orange seed flour $(21.82 \%)$. The orange seed flour had $8.88 \%$ crude fiber which was higher than that of wheat flour $(0.93 \%)$. Similar observation was reported by [17] that deffatting increased the crude fibre concentration of beniseed. The crude fiber contents of the debittered orange 
seed flours ranged from $18.25 \%$ to $21.82 \%$. This high level of fiber is significant in nutrition. Fibre aids in lowering blood glucose level [22]. Health benefits of dietary fiber indicate that dietary fiber may give protection against cardiovascular diseases, diabetes and obesity [23]. A generous intake of dietary fiber reduces risk for developing coronary heart disease, stroke, [24] hypertension, diabetes, obesity, and certain gastrointestinal Disorders [25]. The carbohydrate content of the flours ranged from $33.07 \%-74.94 \%$. Wheat flour had the highest carbohydrate content of $74.94 \%$, while the orange seed flour had $32.24 \%$. However, flours produced from orange seeds boiled for 80 and $120 \mathrm{~min}$ had significantly higher value than the orange seed flour. Similar observation was reported by [17] that deffatting increased the carbohydrate concentration of beniseed. However, there was decrease in the carbohydrate of the orange seed flour produced from the $160 \mathrm{~min}$ boiled orange seed. The result agreed with previous report that increased boiling time increased the carbohydrate content of mungbean but excessive boiling reduced it [26].

\subsection{Functional properties of the flours}

Table 2: Functional properties of orange seed flours and wheat flour

\begin{tabular}{|l|l|l|l|l|l|l|}
\hline Flour & $\begin{array}{l}\text { Oil absorption } \\
\text { capacity } \\
(\mathrm{g} / \mathrm{g})\end{array}$ & Bulk density & $\begin{array}{l}\text { Water } \\
\text { absorption } \\
\text { capacity }(\mathrm{g} / \mathrm{g})\end{array}$ & $\begin{array}{l}\text { Least gelation } \\
\text { concentration } \\
(\%)\end{array}$ & $\begin{array}{l}\text { Foaming } \\
\text { capacity } \\
(\%)\end{array}$ & $\begin{array}{l}\text { Foaming } \\
\text { stability } \\
(\%)\end{array}$ \\
\hline Wheat & $1.87^{\mathrm{b}} \pm 0.82$ & $0.77^{\mathrm{a}} \pm 0.01$ & $1.54^{\mathrm{d}} \pm 0.04$ & 4.00 & $21.11 \pm 0.8$ & $12.50 \pm 0.01$ \\
\hline Orange seed & $1.73^{\mathrm{b}} \pm 0.70$ & $0.66^{\mathrm{b}} \pm 0.01$ & $2.85^{\mathrm{c}} \pm 0.20$ & 10.00 & $2.8 \pm$ & $2.0 \pm 0.01$ \\
\hline OSFB40 & $1.85^{\mathrm{b}} \pm 0.20$ & $0.59^{\mathrm{c}} \pm 0.01$ & $3.74^{\mathrm{b}} \pm 0.21$ & 20.00 & $\mathrm{Nd}$ & $\mathrm{Nd}$ \\
\hline OSFB80 & $2.47^{\mathrm{a}} \pm 0.04$ & $0.46^{\mathrm{d}} \pm 0.02$ & $4.51^{\mathrm{a} \pm 0.20}$ & 20.00 & $\mathrm{Nd}$ & $\mathrm{Nd}$ \\
\hline OSFB120 & $2.64^{\mathrm{a}} \pm 0.20$ & $0.45^{\mathrm{de}} \pm 0.03$ & $4.62^{\mathrm{a}} \pm 0.10$ & 20.00 & $\mathrm{Nd}$ & $\mathrm{Nd}$ \\
\hline OSFB160 & $2.64^{\mathrm{a}} \pm 0.18$ & $0.42^{\mathrm{c}} \pm 0.01$ & $4.67^{\mathrm{a}} \pm 0.05$ & 20.00 & $\mathrm{Nd}$ & $\mathrm{Nd}$ \\
\hline
\end{tabular}

Means within a column with the same superscript were not significantly different $(\mathrm{P}>0.05)$. OSF=orange seed flour, OSFB 40 = orange seed flour boiled for $40 \mathrm{~min}$, OSFB 80 = orange seed flour boiled for $80 \mathrm{~min}$, OSFB120 $=$ orange seed flour boiled for $120 \mathrm{~min}$, and OSFB160 = orange seed flour boiled for $160 \mathrm{~min}, \mathrm{Nd}=$ not detected.

The oil absorption capacity of the flours ranged from $1.73-2.64 \mathrm{~g} / \mathrm{g}$. The orange seed flour had the lowest value $(1.73 \mathrm{~g} / \mathrm{g})$. Debittering methods increased the oil absorption capacity of the orange seed flour. The oil absorption capacity of the seed boiled for 80,120 , and 160 were significantly higher than that of wheat flour $(1.87 \mathrm{~g} / \mathrm{g})$ and orange seed flour. There were significant differences $(\mathrm{p}<0.05)$ in the oil absorption capacity of the flours. The oil absorption capacity of flour is important as it improves the mouth feel and retains the flavor of foods [27]. The oil absorption capacity was comparable to $2.1 \mathrm{ml} / \mathrm{g}$ reported by [14] orange seed flour. This result was higher than those of the undehulled and dehulled sweet orange seed flours $(0.49-0.90 \mathrm{ml} / \mathrm{g})$ reported by [6]. Oil absorption capacity is a prominent factor in food formulations because it improves flavour and increases the mouth feel of foods [28]. Heat treatment increased the oil absorption capacity of seed flour. This increase could be due to both dissociation of the proteins that occur on heating and also due to denaturation which unmasked the non polar residues from the interior of the protein molecule [29]. The bulk density of the flours ranged between 0.42 and $0.77 \mathrm{~g} / \mathrm{cm}^{3}$. There were significant $(\mathrm{p}<0.05)$ differences in the bulk densities of the flour samples. The lowest value was obtained for the flour boiled for $160 \min \left(0.42 \mathrm{~g} / \mathrm{cm}^{3}\right)$ while wheat flour had the highest value $\left(0.77 \mathrm{~g} / \mathrm{cm}^{3}\right)$. Orange seed flour had lower bulk density $\left(0.66 \mathrm{~g} / \mathrm{cm}^{3}\right)$ than wheat flour $(0.77$ $\mathrm{g} / \mathrm{cm}^{3}$ ). Boiling time inversely affected the bulk density of the flour. This implied that increased in boiling time of the orange seed decreased the flour bulk density. The low bulk density of the flours is an advantage in food formulation due to their tendency for retrogradation. Bulk density could be used in determining packaging requirement. The water absorption capacity (WAC) of flours ranged from $1.54-4.67 \mathrm{~g} / \mathrm{g}$. The lowest value of 1.54 was obtained for wheat flour which was lower than that of the orange seed flour $(2.85 \mathrm{~g} / \mathrm{g})$. The debittering methods increased the water absorption capacity of the orange seed flour, values increased with increased boiling time. The water absorption capacity of these flours is useful indication of whether the proteins can be incorporated with the aqueous food formulations, especially, those involving dough handing. Interaction of protein with water is important to properties such as hydration, swelling power, solubility, and gelation [30]. The WAC of the orange seed flour $(2.85 \mathrm{~g} / \mathrm{g})$ was comparable to WHC of orange seed flour $(2.6 \mathrm{ml} / \mathrm{g})$ reported 
by [14], but higher than those of undehulled and dehulled orange seed flours ( 2.2 and $2.4 \mathrm{ml} / \mathrm{g}$ ) reported by [6]. Least gelation concentration (LGC), which is defined as the lowest protein concentration at which gel remained in the inverted tube was used as index of gelation capacity. The orange seed flour had LGC of $10 \%$ which was close to those of the dehulled and undehulled orange seed flours $(10-12 \%)$ reported by [6] and $10 \%$ reported by [14]. The wheat flour had the least LGC value of $4 \%$. The debittered flour had higher value of $20 \%$ probably due to soaking, boiling and defatting. The foaming capacity of wheat flour was $21.11 \%$, which was higher than $2.8 \%$ for orange seed flour. The debittering methods affected the foaming capacity and foaming stability of the orange seed flour. Foams are used to improve texture, consistency and appearance of foods [27]. The foaming stability of wheat flour was $12.50 \%$. Foaming capacity and foam stability of food protein depends on the type of protein, degree of denaturation, $\mathrm{pH}$ and temperature of the medium as well whipping methods [31] [32]. Heat processing decreases the nitrogen solubility by denaturation and also reduces their foaming capacity [32].

\subsection{Functional properties of flour blends}

Table 3: Functional properties of debittered orange seed flour and wheat flour blends

\begin{tabular}{|l|l|l|l|l|l|l|}
\hline $\begin{array}{l}\text { Wheat: } \\
\text { ODFB120 }\end{array}$ & $\begin{array}{l}\text { Water } \\
\text { absorption } \\
\text { capacity } \\
(\mathrm{g} / \mathrm{g})\end{array}$ & $\begin{array}{l}\text { Oil absorption } \\
\text { capacity } \\
(\mathrm{g} / \mathrm{g})\end{array}$ & $\begin{array}{l}\text { Least gelation } \\
\text { concentration } \\
(\%)\end{array}$ & $\begin{array}{l}\text { Bulk density } \\
\left(\mathrm{g} / \mathrm{cm}^{3}\right)\end{array}$ & $\begin{array}{l}\text { Foaming } \\
\text { capacity }\end{array}$ \\
\hline $100: 00$ & $1.54^{\mathrm{f}} \pm 0.06$ & $1.89^{\mathrm{c}} \pm 0.10$ & $4.00^{\mathrm{c}} \pm 0.00$ & $0.78^{\mathrm{a}} \pm$ & $21.11^{\mathrm{a}} \pm 0.82$ & $12.50^{\mathrm{a}} \pm 0.01$ \\
\hline $90: 10$ & $1.78^{\mathrm{e}} \pm 0.03$ & $1.92^{\mathrm{c}} \pm 0.04$ & $4.00^{\mathrm{c}} \pm 0.00$ & $0.75^{\mathrm{b}} \pm$ & $17.46^{\mathrm{b}} \pm 0.38$ & $5.65^{\mathrm{b}} \pm 0.95$ \\
\hline $80: 20$ & $1.91^{\mathrm{d}} \pm 0.05$ & $1.95^{\mathrm{c}} \pm 0.02$ & $4.00^{\mathrm{c}} \pm 0.00$ & $0.73^{\mathrm{c}} \pm$ & $17.13^{\mathrm{b}} \pm 0.44$ & $1.47^{\mathrm{b}} \pm 0.46$ \\
\hline $70: 30$ & $2.10^{\mathrm{c}} \pm 0.06$ & $2.02^{\mathrm{c}} \pm 0.01$ & $4.00^{\mathrm{c}} \pm 0.00$ & $0.71^{\mathrm{d}} \pm$ & $16.72^{\mathrm{bc}} \pm 0.63$ & $1.40^{\mathrm{b}} \pm 0.40$ \\
\hline $60: 40$ & $2.31^{\mathrm{b}} \pm 0.08$ & $2.24^{\mathrm{b}} \pm 0.20$ & $10.00^{\mathrm{b}} \pm 0.00$ & $0.70^{\mathrm{a}} \pm$ & $15.62^{\mathrm{c}} \pm 0.33$ & $1.27^{\mathrm{b}} \pm 0.26$ \\
\hline $00: 100$ & $4.64^{\mathrm{a}} \pm 0.07$ & $2.85^{\mathrm{a}} \pm 0.10$ & $20.00^{\mathrm{a}} \pm 0.00$ & $0.46^{\mathrm{f}} \pm$ & $0.00^{\mathrm{d}} \pm 00$ & $0.00^{\mathrm{c}} \pm 00$ \\
\hline
\end{tabular}

Means within a column with the same superscript were not significantly different $(\mathrm{P}>0.05)$. ODFB120

The water absorption capacity (WAC) of the flour blends ranged from $1.54-4.64 \mathrm{~g} / \mathrm{g}$. Significant differences $(\mathrm{p}<0.05)$ existed in the WAC of the flour blends $(\mathrm{p}<0.05)$. Wheat flour $(100 \%)$ had the lowest WAC $(1.54 \mathrm{~g} / \mathrm{g})$ while the orange seed flour $(100 \%)$ had the highest WAC $(4.64 \mathrm{~g} / \mathrm{g})$. The water absorption capacity also increased with the level of orange seed flour in the blends. The oil absorption capacity (OAC) of the blended flours ranged from $1.89-2.85 \mathrm{~g} / \mathrm{g}$, with wheat flour having the lowest value $(1.89 \mathrm{~g} / \mathrm{g})$ while orange seed flour had the highest value $(2.85 \mathrm{~g} / \mathrm{g})$. The OAC of the composite flours also increased with increased in the level of orange seed flour in the blends. The least gelation concentration (LGC) of the flour blends showed significant differences with values ranging from $4-20 \%$. The $100 \%$ wheat flour had the least value $(4 \%)$. The LGC increased with the level of orange seed flour in the blend. The bulk density of the flour blends ranged from $0.46-0.78 \mathrm{~cm}^{3}$. There was a general decreased in the bulk density as the level of orange seed flour increased in the blends. The foam stability of the flour blends ranged from $0.00-12.50 \%$. There was a general decreased in the foam stability of the flour with increased in the level of debittered orange seed flour in the blends. The foaming capacity of the flour blends ranged from $0.00-21.11 \%$. There was a general decreased in the foam capacity of the flour with increased in the level of debittered orange seed flour in the blends.

\subsection{Pasting properties of blends of flours}

Table 4: Pasting properties of orange seed flour and wheat flour blends

\begin{tabular}{|l|l|l|l|l|l|l|l|}
\hline $\begin{array}{l}\text { Flour } \\
\text { Blends } \\
(\text { WF:OSFB120) }\end{array}$ & $\begin{array}{l}\text { Peak viscosity } \\
(\text { RVU) }\end{array}$ & $\begin{array}{l}\text { Trough } \\
\text { viscosity } \\
\text { (RVU) }\end{array}$ & $\begin{array}{l}\text { Breakdown } \\
\text { viscosity (RVU) }\end{array}$ & $\begin{array}{l}\text { Final } \\
\text { Viscosity } \\
(\text { RVU) }\end{array}$ & $\begin{array}{l}\text { Setback } \\
\text { viscosity } \\
(\text { RVU) }\end{array}$ & $\begin{array}{l}\text { Peak } \\
\text { Time } \\
(\mathrm{min})\end{array}$ & $\begin{array}{l}\text { Pasting } \\
\text { Temp }\left({ }^{\circ} \mathrm{C}\right)\end{array}$ \\
\hline $100: 00$ & 68.67 & 66.00 & 2.67 & 257.33 & 191.33 & 6.33 & 83.65 \\
\hline $90: 10$ & 66.67 & 62.42 & 4.25 & 256.75 & 194.33 & 6.42 & 84.15 \\
\hline 80.20 & 67.92 & 63.25 & 2.67 & 250.00 & 182.75 & 6.45 & 82.55 \\
\hline 70.30 & 66.08 & 62.08 & 4.00 & 235.42 & 173.33 & 6.55 & 84.05 \\
\hline 60.40 & 62.75 & 60.58 & 2.17 & 230.83 & 170.25 & 6.33 & 83.65 \\
\hline $00: 100$ & 50.33 & 46.83 & 3.50 & 120.25 & 73.42 & 6.25 & 82.75 \\
\hline
\end{tabular}

Means within a column with the same superscript were not significantly different $(\mathrm{P}>0.05)$. OSFB120 $=$ orange seed flour boiled for $120 \mathrm{~min}$. 
The peak viscosity of the $100 \%$ wheat flour (68.67 RVU) was the highest and decreased as the debittered orange seed flour level increased in the blends. The peak viscosity of the $100 \%$ debittered orange seed flour was 50.33 RVU. Peak viscosity also indicates the water binding capacity of starch [33]. The relatively high peak viscosity exhibited by wheat and orange seed flour blends is indicative that the flour may be suitable for products requiring high gel strength and elasticity [33]. The relatively low peak viscosity exhibited by the debittered orange seed flour sample is indicative that the flour may not be suitable for products requiring high gel strength and elasticity while being suitable in the preparation of complementary foods. The trough viscosity (TV), which is the minimum viscosity value in the constant temperature phase of the RVA profile and measures the ability of paste to withstand breakdown during cooling ranged between 46.83 and 66.00 RVU. The $100 \%$ Wheat flour had the highest TV of 66 RVU while $100 \%$ orange seed had the lowest TV of 46.83 RVU. The trough value decreased progressively as the level of debittered orange seed flour increased in the blends. The breakdown viscosity of the flours ranged between 2.17 and 4.25 RVU. The breakdown viscosity is an index of the stability of starch. The low values suggest high stability of flour to withstand heat and shear stress. The higher the breakdown viscosity, the lower the ability of the flour to withstand heating and shear stress during cooking [34]. The final viscosity of the $100 \%$ wheat flour was 257.33 RVU and ranged from 120.25 - 257.33 RVU for the other flours. The $100 \%$ debittered orange seed flour had the lowest final viscosity value of 120.25 RVU. The decreased in the final viscosity value of the blends could be attributed to the increased levels of debittered orange seed flour. Final viscosity is used to define the particular quality of flour and indicate the stability of the cooked paste when in actual use. It also indicates the ability of flour to form various paste or gel after cooling. The final viscosity gives an idea of the ability of a material to gel after cooking. Setback viscosity values have been reported to correlate with ability of starches to gel into semi solid pastes [35]. The setback values of the flours ranged from 73.42 - 194.33 RVU. The setback value was higher for $100 \%$ wheat flour (191.33 RVU) than the $100 \%$ orange seed flour (73.42 RVU). The lowest set back value was recorded in $100 \%$ orange seed flour. Increased in orange seed flour in the blends, decreased the setback value. The higher the setback viscosity, the higher the retrogradation of the flour paste, during cooling and the higher the staling rate of the product made from the flour [35]. This implied blending wheat flour with debittered orange seed flour will reduce the staling rate of the product made from blends of the flours.

Peak time is a measure of the cooking time [34]. The peak time ranged between $6.25-6.55 \mathrm{~min}$. The pasting temperature for $100 \%$ wheat flour was $83.65{ }^{\circ} \mathrm{C}$ while it was $82.75{ }^{\circ} \mathrm{C}$ for $100 \%$ orange seed flour. The pasting temperature ranged from $82.55-84.15{ }^{\circ} \mathrm{C}$. The pasting temperature is one of the pasting properties which provide an indication of the minimum temperature required for sample cooking, energy cost involved and other components stability [36]. Hence, the pasting properties of these flours are important indices in predicting the pasting behavior during and after cooking

\subsection{Sensory evaluation of flours}

The sensory properties of orange seed flours and wheat flour are shown in Table 12.

Table 5: Sensory properties of wheat flour and orange seed flours

\begin{tabular}{|l|l|l|l|l|l|l|}
\hline Sample & Appearance & Flavour & Taste & Aftertaste & Texture & General acceptability \\
\hline OSFB40 & $3.4^{\mathrm{c}} \pm 1.50$ & $6.6^{\mathrm{bc}} \pm 1.24$ & $3.2^{\mathrm{c}} \pm 1.61$ & $3.0^{\mathrm{c}} \pm 1.33$ & $4.7^{\mathrm{c}} \pm 1.63$ & $3.5^{\mathrm{c}} \pm 1.26$ \\
\hline OSFB80 & $5.9^{\mathrm{b}} \pm 1.44$ & $7.0^{\mathrm{ab}} \pm 1.49$ & $5.8^{\mathrm{b}} \pm 1.22$ & $6.0^{\mathrm{b}} \pm 1.15$ & $6.6^{\mathrm{b}} \pm 0.96$ & $6.1^{\mathrm{b}} \pm 1.37$ \\
\hline OSFB120 & $7.4^{\mathrm{a}} \pm 1.17$ & $8.0^{\mathrm{a}} \pm 1.41$ & $7.1^{\mathrm{a}} \pm 1.96$ & $6.7^{\mathrm{a}} \pm 1.06$ & $7.1^{\mathrm{b}} \pm 1.44$ & $8.0^{\mathrm{a}} \pm 0.816$ \\
\hline OSFB160 & $6.1^{\mathrm{b}} \pm 1.28$ & $5.7^{\mathrm{c}} \pm 1.25$ & $6.2^{\mathrm{b}} \pm 1.22$ & $6.1^{\mathrm{b}} \pm 1.10$ & $6.8^{\mathrm{b}} \pm 1.14$ & $5.5^{\mathrm{b}} \pm 1.08$ \\
\hline W F & $8.2^{\mathrm{a}} \pm 0.63$ & $5.4^{\mathrm{c}} \pm 1.34$ & $8.1^{\mathrm{a}} \pm 1.28$ & $7.5^{\mathrm{a}} \pm 1.08$ & $8.4^{\mathrm{a}} \pm 0.64$ & $8.4^{\mathrm{a}} \pm 0.70$ \\
\hline
\end{tabular}

Means within a column with the same superscript were not significantly different $(\mathrm{P}>0.05)$. WF $=$ wheat flour, OSFB40 = orange seed flour boiled for $40 \mathrm{~min}$, OSFB80 = orange seed flour boiled for $80 \mathrm{~min}$, OSFB120 = orange seed flour boiled for $120 \mathrm{~min}$, and OSFB160 = orange seed flour boiled for $160 \mathrm{~min}$

The flours varied in their ratings for appearance, flavour, taste, aftertaste, texture, and general acceptability. The wheat flour had the highest ratings in all the parameters except flavour. However, there were no significant differences ( $p>0.05$ ) between control sample and the orange seed flour boiled for 120 min for appearance, taste, aftertaste, and general acceptability, except for flavour and texture. In terms of flavour, flours produced from orange seed had better rating than the wheat flour, scores ranged from 5.7 - 8.0 on 9-point 
Hedonic scale. This may be attributed to the fat content of orange seed flour. However, wheat flour had higher score for texture which was significantly different $(\mathrm{p}<0.05)$ from those of the flour samples produced from orange seeds.

\section{Conclusion}

Debittering of orange seed by soaking, boiling and defatting reduced the bitterness of orange seeds. The debittered orange seed flour had higher fiber, mineral and protein content than the orange seed flour. Oil absorption capacity and water absorption capacity would permit the utilization of debittered orange seed flour in bakery products. The high water absorption capacity of the flours may be used in the formulation of some foods such as sausage, doughs, processed cheese, and baked product. The low bulk density of the flour can be used for food formulation with less fear of retrogradation.

\section{Reference}

[1]. E. I. Oikeh, K. Oriakhi, and E. S. Omoregie, Proximate analysis and photochemical screening of citrus sinensis fruit wastes. The Bioscientist, 1(2), 2013, 164 - 170.

[2]. M. B. Atta, and M. G. El-Shenawi, (2013). Functional properties and in-vitro digestibility of bitter orange (Citrus aurantium) seed flour. Journal of Agricultural Science and Soil Sciences, 3, 2013042 - 047.

[3]. S. S. Kulwant, and K. S. Minhas, Handbook of fruits and fruit processing: oranges and citrus juices. (Oxford, United Kingdom, Blackwell Publishing, 2006) 322 - 325.

[4]. B. B. LalKaushal, and N. K. Thakur, Pilot scale debittering of kinnow juice using adsorbent amberlite XAD-16. Journal of Science and Industrial Research, 60, 2001, 896 - 899.

[5]. A. N. Siddiqui, D. N. Kulkarni, K. D. Kulkarni, and M. Z. Mulla (2013). Studies on debittering of sweet orange juice. World Journal of Dairy and Food Sciences, 8 (2), 2013, 185 - 189.

[6]. M. I. Akpata, and P. I. Akubor, Chemical composition and selected functional properties of sweet orange (Citrus sinensis) seed flour. Plant Foods for Human Nutrition, 54, 1999, 353 - 62.

[7]. I. A. Ihekoronye, and P. O. Ngoddy, (1985). Integrated food science and technology for the tropics. (Macmillan Publishers Limited, London, 1985).

[8]. S.K. Sathe, and D. K. Salunkhe, Functional properties of the great Norhern bean (Phaseolus Vulgaris L).Proteins emulsions foaming viscosity and gelation properties. Journal of Food Science, 46, 1981, 71 - 81.

[9]. C. W. Coffmann, and V. Garciaj, Functional properties and amino acid content of a protein isolate from mungbean flour. Journal of Food Science and Technology, 12, 1977, 473 - 484.

[10]. K. Narayara, and R. M. Narasinga, Effect of partial hydrolysis on winged bean (Psophcocarus tetragonolobus) flour. Journal of Food Science, 49, 1989, 944 - 947.

[11]. T. Noda, S. Tsuda, M. Mori, S.Takigawa, M. Endo, and K. Saito, The effect of harvested dates on the starch properties of various potato cultivars. Journal of Food Chemistry, 86, 2004, 119 - 125.

[12]. A.O.A.C. (2010). Official methods of analysis 18th Edition, (Association of Official Analytical Chemists, Washington, D.C., USA)

[13]. A. E. Mubarak, Nutritional composition and antinutritional factors of mungbean seeds (Phaseolus aureus) as affected by some home traditional processes. Journal of Food Chemistry and Nutrition, 89, 2005, 489 - 495

[14]. B. A. Mohamed, and G. M. El shanawi, Functional properties and in vitro digestibility of bitter orange (citrus aurantium) seed flour. Merit Research Journal of Agricultural Science and Soil Sciences, 1, 2013, 042 - 047.

[15]. F. O. Bobbio, A. A. El-Dash, P. A. Bobbio, and L. R. Rodrigues, Isolation and characterization of the physicochemical properties of starch of jackfruit seeds (Artocarpus heterophyllus). Cereal Chemistry Journal, 55, 1978, 505 - 511.

[16]. R. A. Guimaraes, S. P. Favaro, A. C. Viana, J. B. Braga, V. A. Neto, and M. R. Honer,. Study of the proteins in the defatted flour and protein concentrate of barunuts. Journal 'Ciência e Tecnologia de Alimentos, 3, 2012, 123 - 134.

[17]. M. K. Egbekun, and M. U. Ehieze, Proximate composition and functional properties of full fat and defatted beniseed (Sesamum indicum L.) flour. Plant Foods for Human Nutrition, 51, 1997, 35 - 41.

[18]. G. I. Badifu, and E. M. Akpagher, Effects of debittering methods on the proximate composition organoleptic and functional properties of sesame (Sesamum indicum L.) seed flour. Plant Foods for Human Nutrition, 49(2), 1996, 119 - 26.

[19]. C. O. Okoye, C. N. Ibeto, and J. N. Ihedioha, Preliminary studies on the characterization of orange seed and pawpaw seed oil. American Journal of Food Technology 6, 2011, 422 - 426.

[20]. L. Ajala, The effect of boiling on the nutrients and anti-nutrients in two non conventional vegetables. Pakistan Journal of Nutrition 8 (9), 2009, 1430 - 1433.

[21]. H. Wardlaw, and M. Gordom, (1999). Perspectives of nutrition. (Boston Mc-Gray Hill Publishers, New York) 1773.

[22]. J. W. Anderson, P. Baird, R. H. Davis, S. Ferreri, M. Knudtson, A. Koraym, W. Valerie, and C. L. Williams, Health benefits of dietary fiber, Nutrition Reviews. 67 (4), 2009, 188 - 205.

[23]. G. A. Spiller, CRC Handbook of dietary fiber in human nutrition. 3rd edition. (CRC Press Boca. Raton. Florida, 2001) . pp. 363 365.

[24]. F. Marangoni, and A. Poli, The glycemic index of bread and biscuits is markedly reduced by the addition of a proprietary fiber mixture to the ingredients. Nutrition, Metabolism and Cardiovascular Diseases, 18, 2008, 602 - 605.

[25]. L. J. Karhunen, K. R. Juvonen, and S. M. Flander, A psyllium fiber-enriched meal strongly attenuates postprandial gastrointestinal peptide release in healthy young adults. Journal of Nutrition, 140, 2010, $737-44$. 
[26]. B. Akaerue, and G. I. Onwuka, Effect of processing on the proximate composition of the dehulled and undehulled mungbean (Vigna radiata L. Wilczek) Flours. Pakistan Journal of Nutrition 9 (10), 2010, 1006 - 1016.

[27]. P. I. Akubor, and J. I. Eze, Quality evaluation and cake making potential of sun and oven dried carrot fruit. International Journal of Biosciences, 2, 2012, $19-27$.

[28]. H. M. Manukumar, and K. R. Thribhuvan, In-vitro Evaluation of physicochemical, antioxidant and anti-inflammatory activity of Pomegranate (Punica grantum .L) juice and seed Hydro Extracts. International Journal of Pharmacy and Biological Sciences 5(1), 2014, 131-141

[29]. H. M. Manukumar, V. R. Prathima, S. I. Lokesh, G. Goutham and S. Suresha, Impact of partial defatting on nutritional, mineral, functional properties and effect of solvents to evaluate in-vitro antioxidant, anti-diabetic potentiality from flaxseed (linum usitatissimum) extracts. World Journal of Pharmacy and Pharmaceutical Sciences, 3, 2014, 1406 - 1427.

[30]. H. A. Etudaiye, T. U. Nwabueze and L. O. Sanni, Quality of fufu processed from cassava mosaic disease (CMD) resistant varieties. African Journal of Food Science, 3 (3), 2009, 61 - 67.

[31]. Sikorski, Z. E. (2002). Proteins .In: Chemical and Functional Properties of Food Components (Sikorski, Z. E., ed.) Florida: CRC Press, Inc. pp.133 - 178 .

[32]. Adebowale, K. O. and Lawal, O. S. (2003). Foaming gelation and electrophoretic characteristics of macuna bean (Macuna pruriens) protein concentrate. Food Chemistry, 83: 237 - 246.

[33]. Ikegwu, O. J., Okechukwu, P. E. and Ekumankana, E. O. (2010). Physico-chemical and pasting characteristics of flour and starch from achi Brachystegia eurycoma seed. Journal of food technology, 8: 58 - 66.

[34]. Adebowale, Y. A., Adeyemi, I. A. and Oshodi, A. A. (2005). Functional and physicochemical properties of flour of six mucuna species. African Journal of Biotechnology, 4 (12): 1461 - 1468.

[35]. Oke, M. O., Awonorin, S. O. and Workneh, T. S. (2013). Effect of varieties on physicochemical and pasting characteristics of water yam flours and starches. African Journal of Biotechnology, 12: 1250 - 1256.

[36]. Shimelis, A. E., Meaza, M. and Rakshit, S. (2006). Physico-chemical properties pasting behavior and functional characteristics of flours and starches from improved bean (Phaseolus vulgaris L.) varieties grown in East Africa. Agricultural Engineering International: The International Council on Large Electric Systems journal, 8:18 - 36 . 